\title{
DAMPAK PENERAPAN TRANSAKSI E-COMMERCE MELALUI PEMUNGUTAN PAJAK PENGHASILAN (PPh)
}

\author{
Neneng Sri Suprihatin ${ }^{1}$, Mukhlisah Afriyanti ${ }^{2}$ \\ ${ }^{1,2}$ Jurusan Akuntansi, Fakultas Ekonomi dan Bisnis, Universitas Serang Raya, Jl. Raya Cilegon No. KM. 5, \\ Drangong, Kecamatan Taktakan, Kota Serang, Banten, 42116, Indonesia \\ ${ }^{1}$ E-mail: neneng.sri.beauty@gmail.com
}

\begin{abstract}
This study aims to analyze the implementation of income tax collection (PPh) on e-commerce transactions at KPP Pratama Pandeglang. as well as what obstacles are experienced in implementing Taxation on e-commerce transactions. The study was conducted using descriptive qualitative methods. The population of the study was 180,896, and 60 samples were taken, using the purposive sampling method. Data collected by questionnaire and observation methods, analyzed in detail. The results of the study can be concluded that: 1) Tax collection uses the Self Assessment System method, 2) Constraints in e-commerce tax collection are the e-commerce business people who have not been maximized, socialization has not been done thoroughly and e-commerce transactions that are difficult in the detection of a form of business which has its own problem, namely the difficulty of the government to establish clear and fair tax regulations.
\end{abstract}

Keywords: income taxes (PPh); business e-commerce; collection system

\section{PENDAHULUAN}

Pajak adalah salah satu sumber andalan penerimaan negara selain sumber daya minyak dan gas yang digunakan dalam melaksanakan pembangunan nasional yang bertujuan semata-mata untuk kesejahteraan dan kemakmuran bangsa Indonesia. Pengenaan pajak tidaklah dibebankan bagi seluruh rakyat Indonesia, dasar pengenaan pajak didasarkan pada wajib pajak yang memenuhi syarat sesuai dengan peraturan dan perundang-undangan yang mengaturnya (Makalalag, 2016). Menurut Suriyadi (2015), electronic commerce (ecommerce) adalah salah satu bentuk dari transaksi jual beli antara penjual dan konsumen tanpa melalui proses tatap muka dan mengandalkan transaksi online yang membentuk market atau pasar global dan universal tanpa ada hambatan jarak dan waktu. Perubahan radikal perdagangan di Indonesia dari masa perdagangan konvensional ke masa perdagangan secara elektronik (e-commerce) dengan mengutamakan perdagangan dengan bertumpu pada proses digital sehingga dapat menjadikan pasar lebih efisien (Rosalinawati dan Syaiful, 2018). Menurut Wibawa (2010) dalam Rosalinawati dan Syaiful (2018), perubahan yang terjadi dimulai sejak tahun 1996 dengan adanya toko buku online yang pertama dengan alamat web http://www.sanur.com. Menurut Syadri (2017), salah satu contoh daerah yang mengalami perubahan akibat ekonomi digital adalah Provinsi Jawa Timur yang mengembangkan ekonomi digital e-commerce dengan melihat tingginya potensi pasar. Provinsi Jawa Timur menjadi daerah ketiga terbesar di Indonesia setelah Jakarta dan Jawa Barat.

Menurut Utomo (2013), perdagangan elektronik atau yang lebih dikenal dengan electronic commerce (e-commerce) pada mulanya dilakukan transaksi-transaksi bisnis antar perusahaan besar, serta jasa perbankan dan organisasi lainnya. Namun selanjutnya mengalami perkembangan kepada konsumen rumah tangga yang bersifat perorangan dan penjualan skala kecil. Rahmatullah (2016) menjelaskan bahwa proses jual beli yang ada di e-commerce memiliki perbedaan dengan proses jual beli pada umumnya. Transaksi e-commerce memiliki karakteristik yang khusus sehingga berdampak terhadap penerapan pajak yang lebih sulit dari 
proses jual beli secara elektronik. Hal ini disebabkan karena proses transaksi e-commerce yang dilakukan bersifat online serta paperless transaction yang merupakan dokumen digital bukanlah dokumen seperti lazimnya transaksi biasa. Selain itu pemerintah sebagai regulator perdagangan di Indonesia menerbitkan Undang-Undang tentang Perdagangan (UU nomor 7 tahun 2014) yang memberikan kepastian hukum bagi pelaku perdagangan melalui sistem elektronik (PMSE) baik bagi penjual maupun pembeli. Selain itu pemerintah juga melalui Kementerian Keuangan dalam hal ini Direktorat Jenderal Pajak mengatur dalam hal pengenaan pajak bagi transaksi perdagangan online (e-commerce). Aturan yang terbaru tentang e-commerce pemerintah melalui Menteri Keuangan telah menerbitkan Peraturan Menteri Keuangan nomor 210/PMK.010/2018 tanggal 31 Desember 2018 yang mulai berlaku efektif tanggal 1 April 2019 tentang perlakuan perpajakan atas perdagangan melalui sistem elektronik (e-commerce).

Tabel 1 menjelaskan bahwa progress peningkatan dari tahun ke tahun dari produk yang menggunakan pemasaran online. Hal ini dapat dilihat dari total jumlah penerimaan pajak yang meningkat sebesar Rp. 183.458.758.471 pada tahun 2017 dari tahun sebelumnya 33,33\%. Demikian pula kenaikan terjadi sebesar Rp. 22.614.012.883 atau 3,95\% untuk periode 2017-2018. Berdasarkan Tabel 1 dapat dijelaskan bahwa jumlah penerimaan pajak yang diperoleh dari Kantor Pelayanan Pajak Pratama Pandeglang dari wajib pajak orang pribadi atas usaha produknya yang memasarkan secara online semakin meningkat setiap tahunnya. Peraturan Pemerintah (PP) No. 23 Tahun 2018 yang telah diberlakukan mulai tanggal 1 Juli 2018 membantu wajib pajak yang belum terdaftar untuk membayar pajak penghasilan karena tarif pajak yang lebih kecil dari sebelumnya, yaitu 0,5\%, akan membuat Wajib Pajak lebih mudah dalam menghitung pajak terutang dan diperkirakan data wajib pajak yang terdaftar dan melaporkan pajaknya semakin meningkat. Mangoting dan Sadjiarto (2013) menyatakan bahwa tidak seluruh para wajib pajak tidak memenuhi kewajiban dalam melaksanakan pembayaran pajaknya, ada beberapa faktor yang menjadi dasar perilaku kepatuhan para wajib pajak, diantaranya faktor ekonomi dan faktor non ekonomi. Ada beberapa hal yang mendasari faktor ekonomi antara lain tingkatan aktual pendapatan wajib pajak, besaran pajak, keuntungan pajak, denda, pemeriksaan pajak dan probalilitas audit, sedangkan faktor diluar ekonomi (non ekonomi) diantaranya perilaku wajib pajak, sifat wajib pajak, norma sosial masyarakat, dan persepsi terhadap sistem pajak. Selain kedua faktor terdapat juga faktor lain yang mempengaruhi kepatuhan wajib pajak adalah perilaku sosial dan penegakkan aturan pajak.

Tabel 1. Jumlah penerimaan pajak KPP Pratama Pandeglang

\begin{tabular}{cc}
\hline Tahun & Jumlah \\
\hline 2016 & 366.866 .180 .491 \\
2017 & 550.324 .938 .962 \\
2018 & 572.938 .951 .845 \\
Jumlah & $\mathbf{1 . 4 9 0 . 1 3 0 . 0 7 1 . 2 9 8}$ \\
\hline
\end{tabular}

Sumber : Bagian Pengelolaan Data dan Informasi KPP Pratama Pandeglang

Pada penelitian ini, Pandeglang merupakan lokasi penelitian, dan Pandeglang merupakan salah satu kota di Wilayah Banten yang masyarakatnya gemar melakukan transaksi jual beli secara online. Disisi lain, potensi bisnis online di area Pandeglang mayoritas adalah UMKM namun belum tergarap dengan baik dan harus digali secara optimal. Hingga saat ini pemerintah berupaya mendorong perkembangan UMKM secara online melalui gerakan pelatihan untuk peningkatan kapasitas usaha pelaku UMKM dengan cara memberikan pelatihan pengemasan (packaging) melalui media online serta melakukan sosialisasi pengenaan pajak atas transaksi e-commerce di Kabupaten Pandeglang. Harapan 
pemerintah dengan adanya penyuluhan tersebut dapat mengembangkan pangsa pasar UMKM melalui sistem digital serta menjadikan para pelaku usaha secara online paham tentang pajak atas transaksi e-commerce sehingga dapat memberikan kontribusi pemasukkan pajak. Penelitian ini bertujuan untuk menganalisa pemungutan pajak terhadap transaksi $e$-commerce yang terdaftar di Kantor Pelayanan Pajak Pratama Pandeglang yang didasarkan dari Surat Edaran No. 62 tahun 2013 dan PP No. 23 Tahun 2018 tentang potensi perpajakan dalam rangka intensifikasi perpajakan di bidang e-commerce. Penelitian ini juga bertujuan untuk mengetahui masalah yang dialami dalam melaksanakan pemungutan pajak terhadap transaksi e-commerce dan langkah apa yang dilakukan oleh KPP Pandeglang untuk mengatasi permasalahan yang muncul dari transaksi e-commerce.

\section{TINJAUAN PUSTAKA}

Peraturan Perpajakan e-commerce. Menurut Undang-Undang Nomor 28 Tahun 2007 pasal 1 angka 1 tentang Ketentuan Umum dan Tata Cara Perpajakan, pengertian pajak adalah kontribusi wajib kepada Negara yang tertuang oleh orang pribadi atau badan yang bersifat memaksa berdasarkan Undang-Undang dengan tidak mendapatkan imbalan secara langsung dan digunakan untuk keperluan Negara bagi sebesar-besarnya kemakmuran rakyat. Sistem pemungutan pajak yang berlaku di Indonesia adalah self assessment system yaitu sistem yang memberikan kepercayaan dan tanggung jawab yang lebih besar untuk menghitung, menyetor dan melaporkan sendiri besarnya pajak terutang oleh wajib pajak. Pemerintah dalam hal ini aparat perpajakan berkewajiban melaksanakan pembinaan, penelitian dan pengawasan terhadap pelaksanaan pemenuhan kewajiban pajak, salah satunya pajak penghasilan. Aturan terkait e-commerce diatur dalam Undang-Undang (UU) No. 7 tahun 2014 tentang perdagangan yang menjelaskan kepastian hukum serta kesepahaman mengenai Perdagangan Melalui Sistem Elektronik (PMSE) dan konsumen dalam melakukan kegiatan perdagangan melalui sistem elektronik. Undang-Undang (UU) No. 7 tahun 2014 menyebutkan bahwa setiap pelaku usaha yang memperdagangkan barang dan atau jasa dengan menggunakan sistem elektronik wajib menyediakan data dan atau informasi secara lengkap dan benar. Setiap pelaku usaha dilarang memperdagangkan barang dan atau jasa dengan menggunakan sistem elektronik yang tidak sesuai dengan data dan atau informasi dan penggunaan sistem elektronik tersebut wajib memenuhi ketentuan yang diatur dalam Undang-Undang Informasi dan Transaksi Elektronik. Data dan atau informasi Perdagangan Melalui Sistem Elektronik (PMSE) minimal menyertakan identitas dan legalitas Pelaku Usaha sebagai produsen atau Pelaku Usaha Distribusi, persyaratan teknis barang yang ditawarkan, persyaratan teknis atau kualifikasi jasa yang ditawarkan, harga dan cara pembayaran barang dan atau jasa serta cara penyerahan barang. Undang-Undang Perdagangan mendefinisikan Perdagangan Melalui Sistem Elektronik (PMSE) sebagai perdagangan yang dilakukan melalui serangkaian perangkat dan prosedur elektronik. Jenis pelaku usaha PMSE meliputi pedagang (merchant) dan Penyelenggara Perdagangan Secara Elektronik (PPSE), terdiri atas penyelenggara komunikasi elektronik, iklan elektronik, penawaran elektronik, penyelenggara sistem aplikasi transaksi elektronik, penyelenggara jasa dan sistem aplikasi pembayaran dan penyelenggara jasa serta sistem aplikasi pengiriman barang. Perusahaan PMSE dapat berbentuk orang perseorangan atau badan hukum. Terkait pengenaan pajak, transaksi perdagangan secara elektronik dikenakan pajak sesuai peraturan perundang-undangan yang berlaku. Pelaku usaha yang menjalankan perdagangan secara elektronik wajib tunduk pada ketentuan perpajakan Indonesia karena dianggap memenuhi kehadiran secara fisik dan melakukan kegiatan usaha tetap di Indonesia. Terkait bea materai, pengenaan bea materai terhadap dokumen bukti transaksi elektronik diberlakukan terhadap bukti transaksi yang dilakukan secara tertulis diatas kertas. Situs yang telah diaudit berhak memperoleh trustmark. Situs yang tidak bertanggung jawab dapat dimasukkan dalam 
blacklist. Beberapa kajian hukum yang akan saling terkait dan/atau saling mempengaruhi dengan adanya transaksi e-commerce diantaranya adalah HAKI (UU Hak Cipta No. 19/2002, Rahasia Dagang No.30/2000, Desain Industri No.31/2000, Desain Tata Letak Sirkuit Terpadu No.32/2000, Paten No.14/2001 dan Merk Np.15/2001, Perlindungan konsumen No.8/1999, Persaingan Usaha yang Sehat No.5/1999, KUH Perdata dan UU Transfer Dana No.3/2011.

Pajak Penghasilan. Pajak Penghasilan diatur dalam Undang-Undang Nomor 36 tahun 2008 tentang Pajak Penghasilan adalah pajak yang dipotong atas penghasilan berupa gaji, upah, honorarium, tunjangan dan pembayaran lain dengan nama dan dalam bentuk apapun sehubungan dengan pekerjaan, jasa, atau kegiatan yang dilakukan oleh Wajib Pajak orang pribadi dalam negeri. Pengertian Pajak Penghasilan (PPh) Pasal 21 berdasarkan Peraturan Direktur Jenderal Pajak Nomor PER-32/PJ/2010 adalah pajak atas penghasilan berupa gaji, upah, honorarium, tunjangan dan pembayaran lain dengan nama dan dalam bentuk apa pun sehubungan dengan pekerjaan atau jabatan, jasa, dan kegiatan yang dilakukan oleh orang pribadi subyek pajak dalam negeri. Subjek pajak penghasilan dikenai pajak apabila menerima atau memperoleh penghasilan. Subjek pajak yang menerima atau memperoleh penghasilan dalam Undang-Undang No. 36 tahun 2008 tentang Pajak Penghasilan (PPh) disebut Wajib Pajak. Wajib Pajak dikenai pajak atas penghasilan yang diterima atau diperolehnya selama satu tahun pajak atau dapat pula dikenai pajak untuk penghasilan dalam bagian tahun pajak apabila kewajiban pajak subjektifnya dimulai atau berakhir dalam tahun pajak. Pajak Penghasilan merupakan jenis pajak subjektif yang kewajiban pajaknya melekat pada subjek pajak yang bersangkutan, artinya kewajiban pajak tersebut dimaksudkan untuk tidak dilimpahkan kepada subjek pajak lainnya. Oleh karena itu, dalam rangka memberikan kepastian hukum, penentuan saat mulai dan berakhirnya kewajiban pajak subjektif menjadi penting.

Potensi Pajak Penghasilan atas transaksi e-commerce. Definisi $e$-commerce adalah suatu proses membeli dan menjual produk-produk secara elektronik oleh konsumen dan dari perusahaan ke perusahaan dengan komputer sebagai perantara transaksi bisnis (Laudon dan Laudon, 2014:87). Pemerintah melalui Surat Edaran Dirjen Pajak SE nomor 62/PJ/2013 tentang penegasan kembali tentang pengenaan pajak terhadap transaksi e-commerce ditekankan bahwa pengenaan pajak terhadap transaksi e-commerce tetap mengacu kepada peraturan perundang-undangan perpajakan yang berlaku seperti Undang-Undang Nomor 16 tahun 2009 tentang penetapan Peraturan Pemerintah Pengganti Undang-Undang Nomor 5 tahun 2008 tentang Perubahan Keempat atas Undang-Undang Nomor 6 tahun 1983 tentang Ketentuan Umum Perpajakan dan Tata Cara Perpajakan menjadi Undang-Undang (UndangUndang KUP), Undang-Undang Nomor 36 tahun 2008 tentang pajak penghasilan (UndangUndang PPh) dan Undang-Undang Nomor 42 tahun 2009 tentang Pajak Pertambahan Nilai dan Barang Mewah (Undang-Undang PPN) yang terakhir. Pada Lampiran Surat Edaran nomor 62/PJ/2013 memberikan gambaran tentang proses bisnis, revenue model, dan contoh penerapan ketentuan-ketentuan sebagaimana dimaksud dalam Undang-Undang Ketentuan Umum dan Tata Cara Perpajakan, Undang-Undang Pajak Penghasilan, dan Undang-Undang Pajak Pertambahan Nilai terkait dengan 4 (empat) model transaksi e-commerce, yaitu online marketplace, classified ads, daily deals, dan online retail.

Pengaturan pemungutan pajak penghasilan atas transaksi e-commerce. Pengaturan pemungutan pajak penghasilan atas transaksi e-commerce dalam Surat Edaran Direktur Jenderal Pajak Nomor SE-62/PJ/2013 tentang Penegasan Ketentuan Perpajakan atas transaksi e-commerce adalah sebagai berikut:

1. Proses bisnis jasa penyediaan tempat dan/atau waktu (online marketplace). Objek pajaknya adalah penghasilan dari jasa penyediaan tempat dan/atau waktu dalam media lain untuk penyampaian informasi merupakan objek Pajak Penghasilan $(\mathrm{PPh})$ yang wajib dilakukan pemotongan PPh Pasal 21, Pasal 23, atau Pasal 26. Termasuk dalam pengertian 
media lain untuk penyampaian informasi adalah situs internet yang digunakan untuk mengoperasikan toko, memajang content (kalimat, grafik, video penjelasan, informasi dan lain-lain) barang dan/atau jasa, dan/atau melakukan penjualan. Imbalan sehubungan jasa penyediaan tempat dan/atau waktu dalam situs internet untuk penyampaian informasi dalam contoh proses bisnis online marketplace ini dapat berupa monthly fixed fee, rent fee, registration fee, fixed fee, atau subscription fee. Subjek pajaknya adalah orang pribadi atau badan yang memperoleh penghasilan dari jasa penyediaan tempat dan/atau waktu dalam media lain untuk penyampaian informasi dengan dasar hukum yaitu Pasal 4 ayat (1) dan ayat (2), Pasal 17, Pasal 21, Pasal 23 dan Pasal 26 Undang-Undang PPh. Tarif untuk penyelenggara online marketplace sebagai penyedia jasa yang penghasilannya tidak dikenai pajak yang bersifat final, tarif PPh Pasal 17 diterapkan atas Penghasilan Kena Pajak yang dihitung dari penghasilan bruto dari penjualan yang dikurangi dengan biaya-biaya untuk mendapatkan, menagih, dan memelihara penghasilan serta untuk Wajib Pajak Orang Pribadi dikurangi dengan Penghasilan Tidak Kena Pajak. Pengaturan ini kurang memenuhi prinsip keadilan sebagai salah satu prinsip pengenaan pajak, sebab penghasilan bruto tidak menunjukkan keuntungan bersih dari hasil usaha. Salah satu prinsip pemungutan pajak adalah prinsip keadilan. Seperti halnya produk hukum pajak pun mempunyai tujuan untuk menciptakan keadilan dalam hal pemungutan pajak. Adil dalam perundang-undangan maupun adil dalam pelaksanaannya. Contohnya adalah dengan mengatur hak dan kewajiban para wajib pajak, pajak diberlakukan bagi setiap warga negara yang memenuhi syarat sebagai wajib pajak dan sanksi atas pelanggaran pajak diberlakukan secara umum sesuai dengan berat ringannya pelanggaran. Ketentuan Pemotongan $\mathrm{PPh}$ adalah apabila online marketplace merchant sebagai pengguna jasa adalah Wajib Pajak Orang Pribadi atau Badan yang ditunjuk sebagai pemotong $\mathrm{PPh}$, maka pengguna jasa tersebut wajib melakukan pemotongan PPh Pasal 23, Pasal 21, atau Pasal 26 sesuai dengan ketentuan yang berlaku. Tarif PPh Pasal 23 atas penghasilan dari jasa penyediaan tempat dan/atau waktu dalam media lain untuk penyampaian informasi adalah sebesar 2\% (dua persen) dari jumlah bruto tidak termasuk Pajak Pertambahan Nilai (PPN). Dalam hal penyedia jasa dimaksud tidak memiliki Nomor Pokok Wajib Pajak, besarnya tarif pemotongan adalah lebih tinggi 100\% (seratus persen), yaitu menjadi sebesar 4\% (empat persen) dari jumlah bruto tidak termasuk PPN. Tarif PPh Pasal 26 atas penghasilan dari jasa penyediaan tempat dan/atau waktu dalam media lain untuk penyampaian informasi adalah sebesar $20 \%$ (dua puluh persen) dari jumlah bruto tidak termasuk PPN, atau berdasarkan Persetujuan Penghindaran Pajak Berganda (P3B) yang berlaku.

2. Proses bisnis penjualan barang dan/atau jasa (classified ads). Objek pajaknya adalah penghasilan dari penjualan barang dan/atau penyediaan jasa merupakan objek $\mathrm{PPh}$. Apabila penghasilan dari penjualan barang dan/atau penyediaan jasa merupakan objek pemotongan/pemungutan $\mathrm{PPh}$, maka wajib untuk dilakukan pemotongan/pemungutan $\mathrm{PPh}$. Subjek pajaknya adalah orang pribadi atau badan yang memperoleh penghasilan dari penjualan barang dan/atau penyediaan jasa. Penjual barang atau penyedia jasa dalam contoh proses bisnis online marketplace ini adalah online marketplace merchant. Dasar hukumnya adalah Pasal 4 ayat (1) dan ayat (2), Pasal 17, Pasal 21 dan Pasal 22.

3. Proses bisnis penyetoran hasil penjualan kepada online marketplace merchant oleh penyelenggara online marketplace. Objek pajaknya adalah penghasilan dari jasa perantara pembayaran merupakan objek PPh yang wajib dilakukan pemotongan PPh Pasal 23, Pasal 21, atau Pasal 26. Imbalan sehubungan jasa perantara pembayaran dalam contoh proses bisnis online marketplace ini dapat berupa per sale fee dan/atau tagihan lainnya. Subjek pajaknya adalah orang pribadi atau badan yang memperoleh penghasilan dari jasa perantara pembayaran. Penyedia jasa perantara pembayaran dalam contoh proses 
bisnis online marketplace ini adalah penyelenggara online marketplace. Dasar hukumnya adalah Pasal 4 ayat (1) dan ayat (2), Pasal 17, Pasal 21, Pasal 23, dan Pasal 26 UndangUndang PPh. Tarif untuk pihak penyelenggara online marketplace sebagai penyedia jasa yang penghasilannya tidak dikenai pajak yang bersifat final, tarif $\mathrm{PPh}$ Pasal 17 diterapkan atas Penghasilan Kena Pajak yang dihitung dari penghasilan bruto dari penjualan yang dikurangi dengan biaya-biaya untuk mendapatkan, menagih, dan memelihara penghasilan serta untuk Wajib Pajak Orang Pribadi dikurangi dengan Penghasilan Tidak Kena Pajak. Pemotongan $\mathrm{PPh}$ dilakukan dengan ketentuan apabila online marketplace merchant sebagai pengguna jasa adalah Wajib Pajak Orang Pribadi atau Badan yang ditunjuk sebagai pemotong $\mathrm{PPh}$, maka pengguna jasa tersebut wajib melakukan pemotongan $\mathrm{PPh}$ Pasal 23, Pasal 21, atau Pasal 26 sesuai dengan ketentuan yang berlaku. Tarif PPh Pasal 23 atas penghasilan dari jasa perantara pembayaran adalah sebesar $2 \%$ (dua persen) dari jumlah bruto tidak termasuk PPN. Dalam hal penyedia jasa dimaksud tidak memiliki Nomor Pokok Wajib Pajak, besarnya tarif pemotongan adalah lebih tinggi 100\% (seratus persen), yaitu menjadi sebesar 4\% (empat persen) dari jumlah bruto tidak termasuk PPN.

4. Online retail. Online retail adalah kegiatan menjual barang dan/atau jasa yang dilakukan oleh penyelenggara online retail kepada pembeli di situs online retail. Objek pajaknya adalah penghasilan dari penjualan barang dan/atau penyediaan jasa merupakan objek $\mathrm{PPh}$. Apabila penghasilan dari penjualan barang dan/atau penyediaan jasa merupakan objek pemotongan/pemungutan $\mathrm{PPh}$, maka wajib untuk dilakukan pemotongan/pemungutan $\mathrm{PPh}$. Subjek Pajaknya adalah orang pribadi atau badan yang memperoleh penghasilan dari penjualan barang dan/atau penyediaan jasa. penjual barang atau penyedia jasa dalam contoh proses bisnis online retail adalah penyelenggara online retail. Dasar hukumnya adalah sama dengan dasar hukum bisnis penyetoran hasil penjualan kepada online marketplace merchant oleh penyelenggara online marketplace tersebut di atas. Tarif untuk pihak penyelenggara online retail (sekaligus merchant) sebagai penjual barang atau penyedia jasa yang penghasilannya tidak dikenai pajak yang bersifat final, tarif $\mathrm{PPh}$ Pasal 17 diterapkan atas Penghasilan Kena Pajak yang dihitung dari: (1) penghasilan bruto dari penjualan yang dikurangi dengan biaya-biaya untuk mendapatkan, menagih, dan memelihara penghasilan serta untuk Wajib Pajak Orang Pribadi dikurangi dengan Penghasilan Tidak Kena Pajak; atau (2) penghasilan neto dengan menggunakan norma penghitungan sebagaimana dimaksud dalam Pasal 14 Undang-Undang PPh dan untuk Wajib Pajak orang pribadi dikurangi dengan Penghasilan Tidak Kena Pajak.

Berdasarkan latar belakang yang ada, permasalahan yang terjadi adalah masih banyak diantara pengguna bisnis E-commerce yang masih belum mengetahui bagaimana sebenarnya pelaksanaan pajak yang ada, sehingga tujuan penelitian ini adalah untuk mengetahui apakah pelaksanaan $\mathrm{PPh}$ atas transaksi E-commerce telah sesuai dengan peraturan perpajakan tentang E-commerce yang dibuat oleh pemerintah. Gambar 1 menggambarkan kerangka pemikiran dari penelitian ini. 


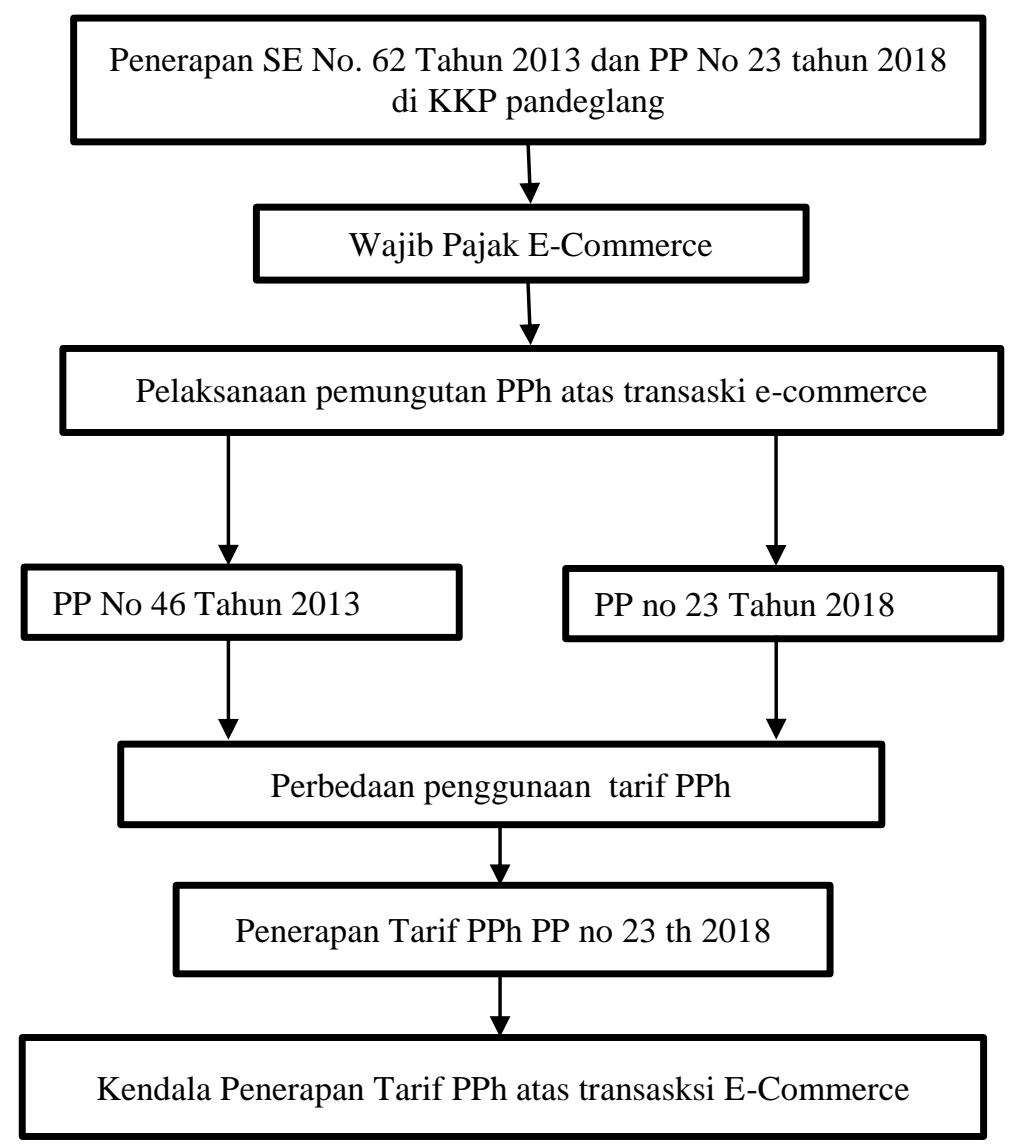

Gambar 1. Kerangka pemikiran

\section{METODE PENELITIAN}

Jenis dan sumber data. Jenis penelitian ini merupakan penelitian analitis dengan pendekatan kualitatif. Penelitian analitis memiliki tujuan untuk membuat deskripsi, gambaran secara sistematis, akurat mengenai fakta-fakta, sifat-sifat serta hubungan antar fenomena yang terdapat pada riset yang dilakukan. Sedangkan penelitian dengan pendekatan kualitatif adalah suatu pendekatan yang menggunakan data berupa kalimat tertulis ataupun lisan, perilaku, peristiwa-peristiwa, pengetahuan atau obyek studi. Penelitian ini melakukan pengamatan terhadap penetapan dan pemberlakuann tax e-commerce untuk memperoleh informasi dari hasil wawancara, dokumentasi dan pengamatan yang berbentuk deskripsi mengenai analisis terhadap penerapan pajak atas transaksi $e$-commerce.

Sampel dan teknik pengambilan sampel. Menurut Sugiyono (2017:116), yang dimaksud dengan sampel adalah bagian dari jumlah dan karakteristik yang dimiliki oleh populasi tersebut. Bila populasi besar dan penelitian tidak mungkin mempelajari semua yang ada pada populasi, misalnya karena keterbatasan dana, tenaga dan waktu maka penelitian dapat menggunakan sampel yang diambil dari populasi itu. Untuk itu sampel yang diambil dari populasi harus betul-betul representative (mewakili). Teknik pengambilan sampel yang digunakan peneliti adalah nonprobability sampling. Menurut Sugiyono (2017:116) nonprobability sampling adalah teknik pengembalian sampel yang tidak memberi peluang atau kesempatan sama bagi setiap unsur atau anggota populasi untuk dipilih menjadi sampel. Teknik sampel yang digunakan penelitian ini adalah sampling purposive. Menurut sampling purposive adalah teknik sampel dengan pertimbangan tertentu. Dalam penelitian ini dapat ditentukan jumlah sampelnya ditentukan pula karena pertimbangan yang sesuai kriteria antara lain Wajib pajak orang pribadi e-commerce, wajib pajak yang memiliki omset melebihi Rp. 
4.800.000.000,- yang akan dijadikan sampel. Jumlah responden ditentukan pula karna pertimbangan yang sesuai kriteria yang akan dijadikan sampel. Tabel 2 menyajikan sampel penelitian dengan metode sampling purposive berdasarkan kriteria yang ditentukan.

Tabel 2. Sampel penelitian

\begin{tabular}{|c|c|c|}
\hline No & Kriteria Sampel & Jumlah Sampel \\
\hline 1 & Wajib pajak orang pribadi $e$-commerce 2018 & 180.896 \\
\hline 2 & WP yang melakukan usaha tidak secara online & $(87.560)$ \\
\hline 3 & WP yang memiliki omset melebihi Rp.4.800.000.000 & $(93.276)$ \\
\hline & & 60 \\
\hline
\end{tabular}

Sumber: Data yang diolah, 2018

Definisi operasional variabel. Operasional variabel adalah mendefinisikan variabel secara operasional berdasarkan karakteristik yang diamati untuk mempermudah penelitian ini untuk melakukan observasi secara cermat terhadap suatu objek penelitian. Secara tidak langsung definisi operasional akan menunjukkan alat ukur yang tepat untuk mengambil data yang sesuai dengan variabel yang akan diukur. Sehingga pada definisi operasional variabel dapat ditentukan parameter yang dijadikan ukuran dalam penelitian. Tabel 3 menunjukkan definisi operasional variabel dari penelitian ini.

Tabel 3. Operasional variabel

\begin{tabular}{|c|c|c|c|}
\hline Variabel & Definisi & Indikator & Skala \\
\hline $\begin{array}{l}\text { Pemungutan Pajak Penghasilan } \\
\text { (X) }\end{array}$ & $\begin{array}{l}\text { Pemungutan adalah peralihan } \\
\text { kekayaan dari sektor swasta } \\
\text { kesektor publik, berdasarkan } \\
\text { undang-undang untuk } \\
\text { membiayai pengeluaran negara } \\
\text { baik yang rutin maupun untuk } \\
\text { pembangunan Metode yang } \\
\text { digunakan dalam pemungutan } \\
\text { pajak atas electronic commerce } \\
\text { adalah self assesment system. } \\
\text { Metode ini suatu sistem yang } \\
\text { memberi wewenang kepada } \\
\text { wajib pajak untuk menentukkan } \\
\text { sendiri besarnya pajak yang } \\
\text { terutang Pajak penghasilan final } \\
\text { merupakan pajak penghasilan } \\
\text { yang pengenaannya sudah final } \\
\text { (berakhir) sehingga tidak dapat } \\
\text { dikreditkan (dikurangkan) dari } \\
\text { total Pajak Penghasilan yang } \\
\text { terutang pada akhir tahun pajak. }\end{array}$ & $\begin{array}{l}\text { (1) terdaftar sebagai wajib pajak } \\
\text { pribadi dikantor pajak; (2) wajib } \\
\text { pajak mempunyai usaha dan } \\
\text { penghasilan; dan (3) adanya } \\
\text { ketetapan undang-undang yang } \\
\text { berlaku (Rahawati, 2016) }\end{array}$ & Ordinal \\
\hline $\begin{array}{l}\text { Wajib pajak pribadi yang } \\
\text { melakukan kegiatan penjualan } \\
\text { secara online (Electronic } \\
\text { Commerce) (Y) }\end{array}$ & $\begin{array}{l}\text { Wajib pajak merupakan } \\
\text { seseorang yang mempunyai } \\
\text { penghasilan dan terdaftar } \\
\text { sebagai wajib pajak yang } \\
\text { mempunyai Nomor Pokok } \\
\text { Wajin Pajak (NPWP). Dan } \\
\text { NPWP merupakan landasan } \\
\text { atau acuan untuk terlihat wajib } \\
\text { pajak membayar kepatuhan } \\
\text { pajaknya. Sedangkan penjualan } \\
\text { secara online bisa dikatakan } \\
\text { sebagai alat promosi untuk } \\
\text { menjual barangnyar seperti } \\
\text { pakaian, teknologi, dan } \\
\text { sebagainya tanpa harus } \\
\text { mengeluarkan tenaga dan waktu } \\
\text { yang lebih banyak. }\end{array}$ & $\begin{array}{l}\text { (1) terdaftar sebagai wajib pajak } \\
\text { dikantor pajak; (2) wajib pajak } \\
\text { mempunyai usaha selain } \\
\text { pekerjaan utama; dan }(3) \\
\text { promosikan produk usaha } \\
\text { melalui media online (Rahawati, } \\
\text { 2016). }\end{array}$ & Ordinal \\
\hline
\end{tabular}

Metode analisis. Teknik analisis untuk penelitian deskriptif adalah menyajikan konsep teoritis dan gambaran umum mengenai objek penelitian. Analisis data dilakukan 
secara manual guna mendeskripsikan atau menjelaskan mengenai Penerapan Pajak terhadap Transaksi E-commerce sesuai dengan apa yang didengar saat wawancara dan dilihat saat observasi tanpa melebihkan atau menguranginya, kemudian hasil deskripsi dianalisis guna mengetahui kendala apa saja yang dialami dalam melakukan penerapan pajak e-commerce. Analisis yang dilakukan yaitu dikantor Pelayanan Pajak Pratama Pandeglang, yang beralamat Jl. Mayor Widagdo No 6 Kabayan, Kecamatan Pandeglang, Kabupaten Pandeglang Banten 42212.

\section{HASIL ANALISIS DAN PEMBAHASAN}

\subsection{Hasil analisis}

Berdasarkan Tabel 4 dapat dijelaskan bahwa pernyataan tentang dari variabel Y adalah wajib pajak pribadi yang melakukan kegiatan penjualan secara online (electronic commerce). Dapat dijelaskan, untuk kategori sangat setuju yang paling banyak dipilih adalah pernyataan no 8 dan 10 berjumlah 28 , yaitu tentang pemungutan pajak tidak dibedakan antara penjualan secara online dan offline, dan diadakan sosialisasi atau pemberitahuan terlebih dahulu, jika nantinya diadakan ketetapan undang-undang atas penjualan secara online. Dapat diberi kesimpulan bahwa banyak nya responden yang mensetujui untuk dilakukan pemungutan pajak bagi wajib pajak yang mempunyai usaha secara online, dengan tujuan untuk mengetahui pendapatan yang mereka peroleh, dan harus adanya sosialisasi jika ada ketetapan undang-undang atas penjualan secara online, dengan tujuan untuk wajib pajak mengetahui tata cara memungut pajak dari pendapatan yang mereka peroleh. Sehubungan dengan kategori setuju, yang paling banyak dipilih yaitu pernyataan nomor 2 berjumlah 43, yaitu wajib pajak yang mempunyai usaha sampingan, selain pekerjaan utamanya. Dapat diberi kesimpulan bahwa banyaknya responden yang mensetujui untuk dilakukan pemungutan pajak bagi wajib pajak yang mempunyai usaha secara online yang diperoleh dari pekerjaan sampingannya, dengan tujuan untuk mengetahui pendapatan yang mereka peroleh. Sehubungan dengan kategori kurang setuju, yang paling banyak dipilih yaitu pernyataan nomor 4 berjumlah 28, yaitu dilakukan pemungutan pajak atas wajib pajak pribadi yang mempunyai usaha penjualan produk secara online. Dapat diberi kesimpulan bahwa adanya responden yang kurang setuju dilakukan pemungutan pajak dari penjualan secara online harus ke kantor pajak untuk dihitung besar atau kecilnya pajak.

Tabel 4. Variabel Wajib pajak pribadi yang melakukan penjualan secara online.

\begin{tabular}{ccccccc}
\hline \multirow{2}{*}{ Pernyataan } & $\mathbf{5}$ & $\mathbf{4}$ & $\mathbf{3}$ & $\mathbf{2}$ & $\mathbf{1}$ & \multirow{2}{*}{$\mathbf{N}$} \\
\cline { 2 - 5 } & $\mathbf{S S}$ & $\mathbf{S}$ & $\mathbf{K S}$ & $\mathbf{T S}$ & $\mathbf{S T S}$ & \\
\hline 1 & 12 & 33 & 15 & 0 & 0 & 60 \\
2 & 12 & 43 & 5 & 0 & 0 & 60 \\
4 & 26 & 33 & 1 & 0 & 0 & 60 \\
5 & 11 & 21 & 28 & 0 & 0 & 60 \\
6 & 21 & 35 & 4 & 0 & 0 & 60 \\
7 & 27 & 31 & 2 & 0 & 0 & 60 \\
8 & 22 & 36 & 2 & 0 & 0 & 60 \\
9 & 28 & 28 & 4 & 0 & 0 & 60 \\
10 & 24 & 30 & 6 & 0 & 0 & 60 \\
11 & 28 & 30 & 2 & 0 & 0 & 60 \\
12 & 23 & 28 & 9 & 0 & 0 & 60 \\
Jumlah & 24 & 26 & 10 & 0 & 0 & 60 \\
\hline
\end{tabular}

Tabel 5 menunjukkan bahwa pernyataan tentang dari judul penelitian, variabel $\mathrm{X}$ adalah pemungutan pajak penghasilan (PPh). Dapat dijelaskan, untuk kategori sangat setuju yang paling banyak dipilih adalah pernyataan No 4 berjumlah 25, yaitu tentang adanya penurunan tarif PPh sesuai dengan PP No 23 Tahun 2018 memudahkan WP yang membayar 
pajak. Dapat diberi kesimpulan bahwa banyak nya responden yang mensetujui bahwa dengan adanya penurunan tarif untuk $\mathrm{PPh}$ yang tarif sebelumnya $1 \%$ dan sekarang menjadi $0.5 \%$ memudahkan wajib pajak untuk membayar pajak penghasilan dari pendapatan yang mereka peroleh. Sehubungan dengan kategori setuju, yang paling banyak dipilih yaitu pernyataan nomor 3 berjumlah 44, pemungutan $\mathrm{PPh}$ dilakukan untuk Wajib pajak pribadi yang mempunyai omzet kurang dari Rp.4.800.000.000 dikenakan tarif 0.5\%. Dapat diberi kesimpulan bahwa banyak nya responden yang mensetujui bahwa dengan dilakukan pemungutan $\mathrm{PPh}$ dengan tarif $0.5 \%$ memudahkan wajib pajak untuk membayar pajak penghasilan dari pendapatan yang mereka peroleh. Sehubungan dengan kategori kurang setuju, yang paling banyak dipilih yaitu pernyataan nomor 2 berjumlah 23, yaitu dilakukan pemungutan pajak atas wajib pajak pribadi yang mempunyai penghasilan dari penjualan secara online. Dapat diberi kesimpulan bahwa adanya responden yang kurang setuju dilakukan pemungutan pajak dari penjualan secara online harus ke kantor pajak untuk dihitung besar atau kecilnya pajak.

Tabel 5 Variabel pemungutan Pajak Penghasilan (PPh)

\begin{tabular}{ccccccc}
\hline \multirow{2}{*}{ Pernyataan } & $\mathbf{5}$ & $\mathbf{4}$ & $\mathbf{3}$ & $\mathbf{2}$ & $\mathbf{1}$ & \multirow{2}{*}{$\mathbf{N}$} \\
\cline { 2 - 6 } & $\mathbf{S S}$ & $\mathbf{S}$ & $\mathbf{K S}$ & $\mathbf{T S}$ & $\mathbf{S T S}$ & \\
\hline 1 & 13 & 35 & 12 & 0 & 0 & 60 \\
3 & 14 & 23 & 23 & 0 & 0 & 60 \\
4 & 12 & 44 & 4 & 0 & 0 & 60 \\
Jumlah & 25 & 34 & 1 & 0 & 0 & 60 \\
\hline
\end{tabular}

\subsection{Pembahasan}

Mekanisme pelaksanaan pemungutan perpajakan atas transaksi e-commerce pada Kantor Pelayanan Pajak Pratama Pandeglang

Pihak pajak dalam mengadakan pengawasan serta penanganan terhadap perpajakan dibidang electronic commerce memerlukan langkah yang tepat didalam penerapannya. Hal tersebut karena pada subjek dan objek pajak adalah pihak-pihak yang terlibat didalam dunia maya yang secara fisik sulit untuk ditemukan. Kegiatan electronic commerce sendiri merupakan kegiatan perdagangan yang menggunakan jaringan elektronik. Para pelakunya tidak dapat diidentifikasi langsung secara fisik, karena kegiatannya yang berada didunia maya. Kemudian terlihat bahwasanya masih perlu adanya pengawasan serta penanganan yang dilakukan dalam aspek perpajakan dibidang electronic commerce. Permasalahan yang terjadi adalah terletak pada siapa subjek dan apa objek pajak yang melekat pada transaksi ini. Diperlukan pemahaman yang lebih terkait mekanisme serta aspek perpajakan yang melekat untuk kegiatan electronic commerce ini. Data-data laporan keuangan yang terjadi didalam suatu objek perpajakan menjadi penanganan yang mendapatkan sedikit kesulitan dalam hal pengenaan perpajakan. Didalam electronic commerce tidak ada perbedaan dengan transaksi perdagangan secara konvensional, hanya saja karena transaksi yang digunakan melalui media elektronik, maka menjadi hal yang penting dalam penegasan aspek perpajakannya. Sesuai dengan Surat Edaran Direktorat Jendral Pajak Nomor SE-62/PJ/2013 tentang penegasan Ketentuan Perpajakan atas Transaksi electronic commerce disana telah dijelaskan bahwasanya perlu adanya pengoptimalan dalam potensi penerimaan pajak dari transaksi electronic commerce. Secara garis besar, karena model transaksi yang cukup sederhana serta kegiatan yang dapat dilakukan dimana saja, maka transaksi ini menjadi daya tarik tersendiri bagi para pelakunya. Dalam penanganan yang telah dilakukan oleh pihak Direktorat Jendral Pajak terdapat empat model transaksi electronic commerce beserta aspek perpajakannya. Untuk $\mathrm{PPh}$ dapat dihitung berdasarkan peredaran usaha, penghasilan lain maupun penghasilan bruto dikalikan tarif PP No 23 tahun 2018 yaitu 0,5\%. Dilihat dari segi 
pemungutan,sebenarnya pihak pajak tidak memungut pajak melainkan pihak pajak memberi kepercayaan kepada wajib pajak untuk menghitung pajak terutang yaitu dengan menggunakan metode self assessment system. Self assessment system adalah suatu sistem perhitungan pajak yang memberi wewenang kepada wajib pajak untuk menentukan sendiri besarnya pajak yang terhutang. Kemudian untuk perhitungan pemungutan nya sendiri, sama halnya dengan perhitungan pemungutan undang-undang perpajakan yang berlaku.hanya saja untuk penghasilan yang didapat itu dikenakan $0,5 \%$ dari omzet, jumlah omzet dibawah Rp.4.800.000.000 terhitung semua pajak terutang kecuali.

Kendala yang di hadapi dalam penerapan pajak e-commerce pada Kantor Pelayanan Pajak Pratama Pandeglang

Kesadaran serta pemahaman perpajakan wajib pajak yang belum maksimal. Perpajakan diIndonesia menganut sistem self assessment. Wajib pajak (WP) diberi kepercayaan dan tanggung jawab sepenuhnya untuk menghitung, menyetor, dan melaporkan secara teratur kewajiban perpajakannya kepada kantor pelayanan pajak atau KPP. Sebagaimana diamanatkan oleh konstitusi, pelayanan publik yang sama menjadi hak bagi setiap warga negara, namun di sisi lain setiap warga negara juga memiliki kewajiban yang sama untuk berpartisipasi membangun negara melalui pajak. Pajak terhadap transaksi $E$ Commerce dinilai memiliki peran yang sangat penting dalam kepentingan suatu negara. Sehubungan dengan kategori kurang setuju, yang paling banyak dipilih yaitu pernyataan nomor 4 berjumlah 28, yaitu dilakukan pemungutan pajak atas wajib pajak pribadi yang mempunyai usaha penjualan produk secara online. Dapat diberi kesimpulan bahwa adanya responden yang kurang setuju dilakukan pemungutan pajak dari penjualan secara online harus kekantor pajak untuk dihitung besar atau kecilnya pajak. Kesadaran serta Pemahaman Perpajakan Wajib Pajak yang belum maksimal dapat dilihat dari penerimaan pajak nya kenaikannya sangat sedikit per tahunnya.

Sosialisasi belum dilakukan secara menyeluruh. Kesadaran dan Pemahaman dari para Wajib Pajak berbanding lurus dengan sosialisai yang belum dilakukan secara menyeluruh oleh Fiskus. Menurut Rambudi Bagas, sosialisasi mengenai Pajak terhadap transasksi E-Comerce sudah pernah dilakukan pada saat awal keluarnya Surat Edaran No 62 tahun 2013. Aturan tersebut telah diperbarui pemerintah melalui Menteri Keuangan telah menerbitkan Peraturan Menteri Keuangan nomor 210/PMK.010/2018 tanggal 31 Desember 2018 yang mulai berlaku efektif tanggal 1 April 2019 tentang Perlakuan Perpajakan Atas Perdagangan melalui Sistem Elektronik (E-Commerce). Namun, pertumbuhan pelaku bisnis yang makin pesat, dirasa sangat diperlukan untuk sosialisasi kembali, beberapa Wajib Pajak yang sempat menjadi informan pun mengaskan bahwasannya mereka belum pernah mendapatkan sosialisasi terkait Pajak atas transaksi E-Commerce, dan mereka menginginkan sosialisasi tersebut agar dapat memahami perpajakan terutama pada perpajakan terhadap transaksi e-commerce, mengingat tidak semua pembisnis memiliki latar belakang pendidikan dari lulusan ekonomi.

Sistem pengawasan belum maksimal. Bahwa untuk posisi sekarang, hanya sebatas himbauan, yang bergerak adalah bagian ekstensifikasi dari Kantor Pajak Pratama. Untuk WP yang sudah ada di sistem, perpajakannya akan masuk kedalam pengawasan sendiri. Sementara WP yang belum masuk sistem akan masuk kedalam estensifikasi. Caranya masih di pikirkan oleh Fiskus, bagaimana cara yang tepat untuk memajaki dengan effort yang lebih sedikit, jadi untuk Kantor Pajak Pratama tidak lagi harus mencari satu per-satu wajib pajak. 


\section{KESIMPULAN DAN SARAN}

\subsection{Kesimpulan}

Berdasarkan hasil uraian maka dapat disimpulkan bahwa: (1) pemungutan pajak menggunakan metode selfassessment system, yaitu suatu sistem pemungutan pajak yang memberi wewenang kepada wajib pajak untuk menentukan sendiri besarnya pajak yang terutang; dan (2) kendala dalam penerapan pelaksanaan pemungutan pajak penghasilan terhadap transaksi e-commerce adalah: (a) kesadaran serta Pemahaman Perpajakan Wajib Pajak yang belum maksimal; (b) sosialisasi belum dilakukan secara menyeluruh; dan (c) sistem pengawasan belum maksimal.

\subsection{Saran}

Saran dari penelitian ini adalah: (1) perlu dilakukan berbagai program atau kegiatan dalam sosialisasi tentang peraturan pajak yang mengatur transaksi $e$-commerce sesuai dengan aturan yang terbaru tentang e-commerce pemerintah melalui Menteri Keuangan telah menerbitkan Peraturan Menteri Keuangan nomor 210/PMK.010/2018 tanggal 31 Desember 2018 yang mulai berlaku efektif tanggal 1 April 2019 tentang Perlakuan Perpajakan Atas Perdagangan melalui Sistem Elektronik (E-Commerce); dan (2) bagi penelitian selanjutnya disarankan untuk menambahkan variabel seperti pemeriksaan pajak dan kepatuhan wajib pajak yang menjalankan transaksi e-commerce.

\section{DAFTAR PUSTAKA}

Laudon, K. C., \& Laudon, J. P. (2014). Management information systems: Managing the digital firm, $13^{\text {th }}$ Edition. United Kingdom: Pearson Education Limited.

Makalalag, L. (2016). Pengenaan pajak penghasilan terhadap pengusaha dalam transaksi perdagangan online (E-Commerce). Legal Opinion: Jurnal Ilmu Hukum, 4(1) 1-10. https://www.neliti.com/id/publications/150702/pengenaan-pajak-penghasilanterhadap-pengusaha-dalam-transaksi-perdagangan-onlin\#cite

Mangoting, Y., \& Sadjiarto, A. (2013). Pengaruh postur motivasi terhadap kepatuhan wajib pajak orang pribadi. Jurnal Akuntansi dan Keuangan, 15(2), 106-116. https://jurnalakuntansi.petra.ac.id/index.php/aku/article/view/18893

Peraturan Direktorat Jenderal Pajak Nomor PER-32/PJ/2010 Tahun 2010 tentang pelaksanaan pengenaan pajak penghasilan pasal 25 bagi wajib pajak orang pribadi pengusaha tertentu.

Peraturan Menteri Keuangan Nomor PMK Nomor 210/PMK.010/2018 tentang perlakuan perpajakan atas transaksi perdagangan melalui sistem elektronik (e-commerce).

Rahawati, L. (2016). Pengaruh jumlah wajib pajak efektif dan penagihan pajak dengan surat paksa terhadap penerimaan pajak (Studi kasus pada Kantor Pelayanan Pajak Pratama Purwakarta). Universitas Komputer. https://elib.unikom.ac.id/gdl.php?mod=browse\&op=read\&id=jbptunikompp-gdllusyrahmaw-35469\&q=wajib\%20pajak\%20efektif

Rahmatullah, T. (2016). Analisis yuridis atas perlakuan pajak terhadap transaksi e-commerce. https://www.researchgate.net/publication/326694301_ANALISIS_YURIDIS_ATAS PERLAKUAN_PAJAK_TERHADAP_TRANSAKSI_E-COMMERCE

Rosalinawati, E., \& Syaiful, S. (2018). Analisis pajak penghasilan atas transaksi e-commerce di Kabupaten Gresik. Journal of Islamic Accounting and Tax, 1(1), 1-18. http://dx.doi.org/10.30587/jiatax.v1i1.443

Sugiyono, P. D. (2017). Metode penelitian bisnis: Pendekatan kuantitatif, kualitatif, kombinasi, dan R\&D. 
Surat Edaran Pajak Nomor SE-62/PJ/2013 tentang Penegasan Ketentuan Perpajakan atas Transaksi E-Commerce.

Suriyadi. (2015). Pengaturan perpajakan e-commerce dan penghindaran pajak berganda. Tesis. Universitas Airlangga. http://repository.unair.ac.id/id/eprint/33919

Syadri, M. (2017). Jawa Timur Provinsi Terbesar Ketiga Pasar E-Commerce. https://www.jawapos.com/ekonomi/bisnis/04/03/2017/jawa-timur-provinsi-terbesarketiga-pasar-e-commerce/

Undang-Undang No 28 Tahun 2007 Tentang Perubahan Ketiga Atas Undang-undang No.6 Tahun 1983 Tentang Ketentuan Umum dan Tata Cara Perpajakan.

Undang-Undang Nomor 36 Tahun 2008 tentang Perubahan Keempat atas Undang-Undang Nomor 7 Tahun 1983 tentang Pajak Penghasilan

Undang-Undang Nomor 7 tahun 2014 tentang Perdagangan

Utomo, E. M. (2013). Transaksi e-commerce sebagai potensi penerimaan pajak di Indonesia. Jurnal Akuntansi Akunesa, 2(1), 1-20. https://jurnalmahasiswa.unesa.ac.id/index.php/jurnal-akuntansi/article/view/6516 